\title{
Clinical Measurement
}

Takashi Matsukawa MD, Daniel I. Sessler MD, * Makoto Ozaki Mə, ${ }^{\dagger}$ Kazuyuki Hanagata MD, Hironobu Iwashita MD, Teruo Kumazawa. MD

\section{Comparison of distal oesophageal temperature with "deep" and tracheal temperatures}

Purpose: To compare distal oesophageal (reference) temperature with "deep-sternal," "deep-forehead," and tracheal temperatures, establishing the accuracy and precision of each.

Methods: We studied 20 patients undergoing general anaesthesia for gynaecological surgery. Their lungs were mechanically ventilated with a circle system, at a fresh-gas flow rate of $6 \mathrm{~L} \cdot \mathrm{min}^{-1}$ Respiratory gases were not warmed or humidified. Tracheal temperatures were recorded from a Trachelon ${ }^{\circledR}$ tube inserted $\approx 21 \mathrm{~cm}$. Deepbody temperatures were measured at the sternum and forehead using a Coretemp ${ }^{\circledR}$ thermometer. The principle of the method is to null thermal flux through a cutaneous disk, thus obliterating thermal gradients between the sides of the disk, skin surface, and subcutaneous tissues. Distal oesophageal temperatures were measured from thermoi-ouples incorporated into oesophageal stethoscopes. Tracheal and deep-tissue temperatures were compared with oesophageal temperature using regression and Bland and Altman analyses.

Results: Tracheal, sternal, and forehead temperatures correlated similarly with distal oesophageal temperature, correlation coefficients $\left(r^{2}\right)$ being 0.7 in each case. The offset (oesophageal temperature minus study site) was considerably larger for tracheal temperature $\left(0.7^{\circ} \mathrm{C}\right)$ than for the other sites $\left(0.2^{\circ} \mathrm{C}\right)$. However, the precision was only $0.3^{\circ} \mathrm{C}$ at each site.

Conclusion: Our data suggest that tracheal temperatures may not be an adequate substitute for conventional core-temperature monitoring sites. In contrast, the accuracy and precision of deep-tissue temperature monitoring at the sternum and forehead was sufficient for clinical use.

Objectif : Comparer la température oesophagienne distale (référence) avec la température sternale profonde, frontale profonde et trachéale, dans le but de vérifier l'exactitude et la précision de chacune des méthodes.

Méthodes : Vingt patientes subissant un intervention gynécologique ont été étudiées. Elles étaient ventilées mécaniquement à l'aide d'un circuit circulaire, avec un débit de' gaz frais de $6 \mathrm{~L} \cdot \mathrm{min}^{-1}$. Les gaz respiratoires riétaient ni réchauffés ri humidifiés. La température trachéale était enregistrée sur un tube Trachelon ${ }^{\circledR}$ inséré à $\approx 21 \mathrm{~cm}$. Les températures corporelles profondes étaient mesurées au stemum et sur le front avec un thermomètre Coretemp ${ }^{\circledR}$. Le principe de la méthode est d'annuler le flux thermique à travers un disque cutané, et d'oblitérer ainsi les gradients thermiques ertre les côtés du disque, la surface cutanée et le tissu sous-cutané. La température oesophagienne distale était mesurée à l'aide de thermocouples incorporés dans des stéthoscopes oesophagiens. La température trachéale et celle des tissus profonds étaient comparées par analyse de régression et par la méthode de Bland et Altman. Résultats : Les températures distale, sternale et frontale étaient en corrélation identique avec la température oesophagienne distale, le coefficient de corrélation $\left(r^{2}\right)$ étant 0,7 dans chaque cas. La température différentielle (la température oesophagienne moins celle du site étudié) était beaucoup plus importante pour la température oesophagienne $\left(0,7^{\circ} \mathrm{C}\right)$ que pour les autres sites $\left(0,2^{\circ} \mathrm{C}\right)$. Cependant, à chacun des sites, la précision r'était que de $0,3^{\circ} \mathrm{C}$.

Conclusion : Nos données suggèrent que la température trachéale pourrait ne pas être un substitut valable pour le monitorage des sites conventionnels de la température centrale. Par contre, l'exactitude et la précision du monitorage tissulaire profond au niveau du front et du sternum sont suffisants pour l'usage clinique.

From the Department of Anaesthesia, Yamanashi Medical University, the Department of Anaesthesia, *University of California, San Francisco and Department of Anesesthesia and Intensive Care, University of Vienna, Austria, and the Department of Anaesthesia, †Tokyo Women's Medical College.

Address correspondence to: Takashi Matsukawa MD, Department of Anaesthesia, Yamanashi Medical University, Tamaho, Nakakoma, Yamanashi 409-38, Japan. Phone \& Fax: +81-552-73-6755: E-mail: takashim@res.yamanashi-med.ac.jp

Supported by NIH Grant GM49670, the Joseph Drown Foundation (Los Angeles, CA), and the Anaesthesia Patient Safety Foundation (Ermire, PA). Mallinckrodt Anaesthesiology Products, Inc. (St. Louis, MO) donated the thermocouples we used. Terumo Medical, Inc.

(Tokyo, Japan) loaned the authors a Coretemp "deep body" thermometer and provided endotracheal tubes. Accepted for publication December 9, 1997. 
$\mathrm{P}$ ERIOPERATIVE thermal disturbances are common during anaesthesia, with up to $80 \%$ of unwarmed surgical patients becoming hypothermic (core temperature $<36^{\circ} \mathrm{C}$ ). ${ }^{\mathrm{I}}$ Intraoperative hypothermia prolongs drug action ${ }^{2}$ by decreasing metabolism, ${ }^{3}$ causes protein wasting, ${ }^{4}$ impairs platelet ${ }^{5}$ and clotting-cascade enzyme function, ${ }^{6}$ and triggers postanaesthetic shivering. ${ }^{7}$ More importantly, core temperatures only $2^{\circ} \mathrm{C}$ below normal are associated with adverse patient outcomes including prolonged postanaesthetic recovery, ${ }^{8}$ increased bleeding and transfusion requirement, ${ }^{9}$ myocardial ischaemia, ${ }^{10}$ and reduced resistance to surgical wound infection and prolonged hospitalization. ${ }^{11}$ Conversely, hyperthermia can indicate infectious fever, allergic reactions, and skeletal muscle hypermetabolism. ${ }^{12}$

To detect thermal perturbations, continuous core temperature monitoring is now routine when general anaesthesia is administered for more than $\mathbf{3 0} \mathrm{min}$. Temperature monitoring is also appropriate when regional anaesthesia is used for large operations because hypothermia is also common during spinal and epidural anaesthesia. ${ }^{13}$ Because even small changes in core temperature are associated with major adverse outcomes as described above, there is renewed interest in quantifying the accuracy and precision of both commonly-used and proposed temperature-monitoring sites and methods.

Tympanic membrane, nasopharyngeal, oesophageal, and pulmonary artery temperatures are generally considered reliable. ${ }^{14,15}$ The mouth, axilla, bladder, and rectum are suitable under some circumstances, although these sites are less accurate than generally appreciated. ${ }^{16-18}$ Core temperature is frequently monitored in the distal oesophagus during general anaesthesia, that site having proved convenient, safe, and reliable. ${ }^{15}$ However, tracheal temperature has been proposed as an easier alternative in patients requiring endotracheal intubation. ${ }^{19,20}$ Although this method has been used during cardiopulmonary bypass, ${ }^{21}$ experience during routine anaesthetic practice remains limited.

Distal oesophageal temperature is suitable during endotracheal anaesthesia. However, core-temperature monitoring remains problematic in patients whose tracheas are not intubated, including those having regional anaesthesia or general anaesthesia administered with a laryngeal mask. Fortunately, thermodynamic theory supports substituting "deep-tissue" temperature for conventional core-temperature monitoring sites. ${ }^{22,23}$ Deep tissue temperature monitoring was developed by Fox ${ }^{22,24}$ and subsequently refined by other investigators. ${ }^{23,25}$ The basis of the method is to null thermal flux through a cutaneous disk, thus oblit- erating thermal gradients between the sides of the disk, skin surface, and subcutaneous tissues. In practice, this consists of heating the upper surface of an insulated disk such that its temperature equals that of the lower surface. Under conditions of zero flux, temperatures of the upper and lower disk surfaces equal that of the adjacent subcutaneous ("deep") tissue.

Although studies indicate that this technique correlates well with core temperature, ${ }^{25,26}$ experience remains restricted. Accordingly, we compared distal oesophageal (reference) temperature with "deep-sternal," "deep-forehead," and tracheal temperatures, establishing the accuracy and precision of each.

\section{Methods}

With approval of the Ethics Committee of the Yamanashi Medical University Hospital, we studied 20 ASA physical status 1 and 2 patients undergoing lower-abdominal gynaecological surgery scheduled to last at least two hours. Preanaesthetic medication consisted of $0.5 \mathrm{mg}$ atropine $i m$, and $1.5-2.0 \mathrm{mg}$ midazolam im. General anaesthesia was induced with $5 \mathrm{mg} \cdot \mathrm{kg}^{-1}$ of thiamylal and $0.1 \mathrm{mg} \cdot \mathrm{kg}^{-1}$ of vecuronium bromide iv was given to facilitate tracheal intubation. A Trachelon ${ }^{\circledR}$ endotracheal tube (Terumo Corp., Tokyo, Japan), was inserted and positioned using standard clinical criteria (cuff passed $1 \mathrm{~cm}$ through the vocal cords under direct visualization). The tracheal cuff was inflated, as usual, with $5 \mathrm{ml}$ air, sufficient to prevent loss of pulmonary gas at a sustained pressure of $30 \mathrm{~cm} \mathrm{H}_{2} \mathrm{O}$. Anaesthesia was maintained with sevoflurane at an end-tidal concentration of $1.0-3.0 \%$ and $66 \%$ nitrous oxide in oxygen.

Additional vecuronium was administered, as needed, to maintain one to two twitches in response to supramaximal train-of-four electrical stimulation of the ulnar nerve at the wrist. The lungs were mechanically ventilated using a partially re-breathing circle system (Modulus $\mathrm{CD}^{\circledast}$, Ohmeda, Liberty Corner, NJ, USA), at a fresh-gas flow rate of $6 \mathrm{~L} \cdot \mathrm{min}^{-1}$, to maintain end-tidal $\mathrm{PCO}_{2}$ near $35 \mathrm{mmHg}$. Respiratory gases were not warmed or humidified. A full-length circulating-water mattress heated to $38^{\circ} \mathrm{C}$ was positioned under each patient. Intravenous fluids were warmed to $37^{\circ} \mathrm{C}$ and ambient room temperature was maintained near $25^{\circ} \mathrm{C}$. A single layer of standard surgical draping covered each patient.

Deep body temperatures were measured both at the middle of the sternum and mid-forehead using a Coretemp "deep-tissue" thermometer (Terumo Corp.). The sensor elements, $2.5 \mathrm{~cm}$ in diameter were affixed securely with tape at the time of anaesthetic induction. Tracheal temperatures were monitored from 
thermistors incorporated into endotracheal tubes. Distal oesophageal temperatures were measured from thermocouples incorporated into oesophageal stethoscopes (Mallinckrodt Anaesthesiology Products, Inc., St. Louis, MO, USA). The stethoscopes were positioned at the point of maximal heart sounds. All temperatures were recorded at 15 -min intervals, starting 15 min after induction of anaesthesia.

Distal oesophageal temperature was considered the reference value. Temperatures at the other three sites were compared with oesophageal temperature using regression and Bland and Altman analyses. ${ }^{27}$ We determined, a priori, anl accuracy (mean difference between reference and test temperatures) and precision (standard deviation of the difference) of $0.5^{\circ} \mathrm{C}$ to be clinically adequate. The limit of $0.5^{\circ} \mathrm{C}$ was chosen because this variation is typical for other commonly-used temperature measuring sites such as the axilla and mouth. ${ }^{17}$ Results are expressed as mean \pm SD.

\section{Results}

The patients' height was $157 \pm 6 \mathrm{~cm}$, weight $54 \pm 6 \mathrm{~kg}$, and age $48 \pm 14 \mathrm{yr}$. One hundred and sixty-nine temperature sets were recorded. Oesophageal temperatures ranged from 34.5 to $37^{\circ} \mathrm{C}$.

Tracheal, sternal, and forehead "deep" temperatures correlated similarly with distal oesophageal temperature, correlation coefficients $\left(r^{2}\right)$ being 0.7 in each case. The offset (oesophageal temperature minus study site) was considerably larger for tracheal temperature $\left(0.7^{\circ} \mathrm{C}\right)$ than for the other sites $\left(0.2^{\circ} \mathrm{C}\right)$. However, the standard deviations of the differences were comparable and relatively small $\left(0.3^{\circ} \mathrm{C}\right)$ at each site (Table, Figures 1, 2).

\section{Discussion}

The major finding of this study was that tracheal, "deep sternal", and "deep forehead" temperatures correlated similarly with distal oesophageal temperature. The offset (oesophageal temperature minus study site) was considerably larger for tracheal temperature

TABLE Comparison of Distal Oesophageal Temperature with "Decp Sternal," "Deep Forehead," and Tracheal Temperatures.

\begin{tabular}{lllll}
\hline & & Sternum & Forehead & Trachea \\
\hline Regression & & & & \\
& $\mathrm{r}^{2}$ & 0.74 & 0.69 & 0.67 \\
& Slope & 0.91 & 0.90 & 1.00 \\
Bland \& Altman & & & & \\
& Mean $\left({ }^{\circ} \mathrm{C}\right)$ & 0.1 & 0.2 & 0.7 \\
& $\operatorname{SD}\left({ }^{\circ} \mathrm{C}\right)$ & 0.3 & 0.3 & 0.3 \\
\hline
\end{tabular}

Bland \& Altman: Limit; of Agreement by Bland and Altman. ${ }^{27}$

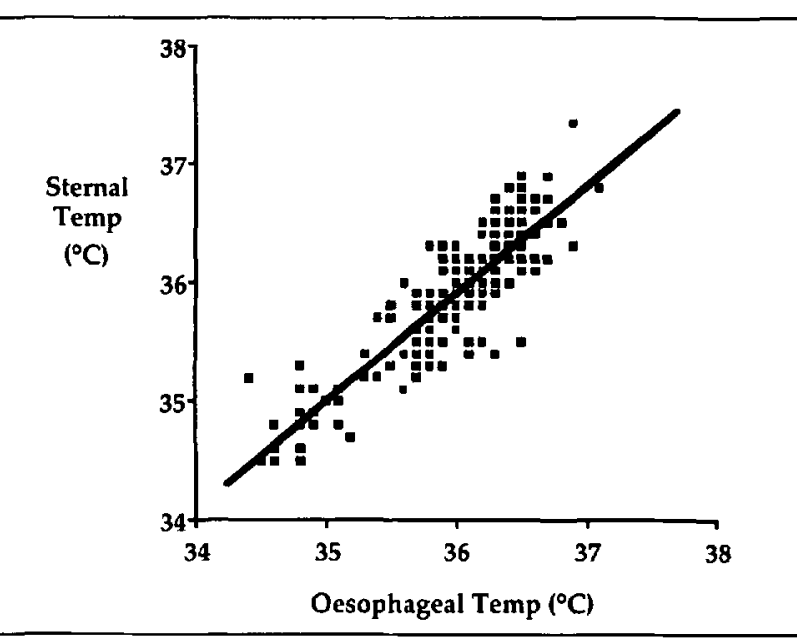

FIGURE 1A Regression comparison of distal oesophageal temperature with "deep sternal" (A), "deep forehead" (B), and tracheal $\left({ }^{\circ} \mathrm{C}\right)$ temperatures. The correlation coefficients were 0.74 , 0.69 , and 0.67 , respectively.

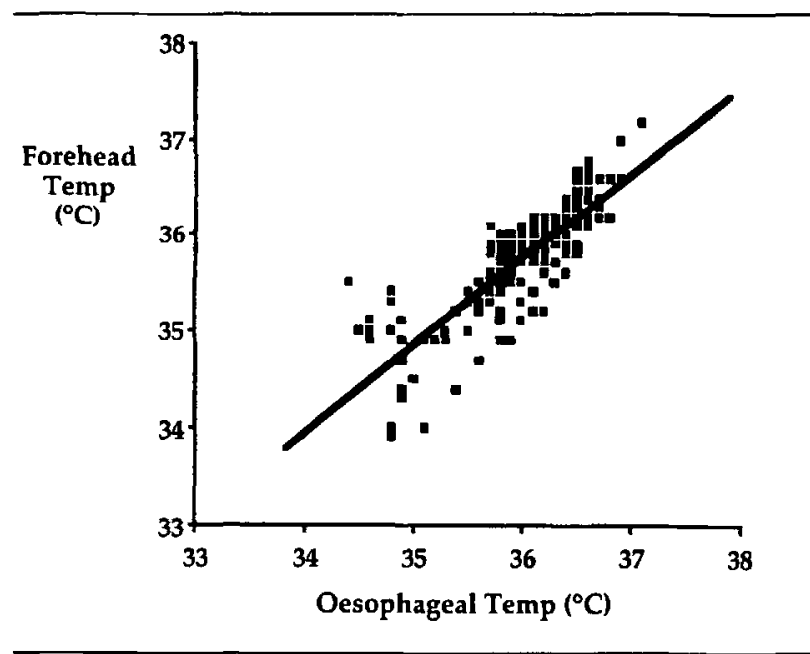

FIGURE 1B

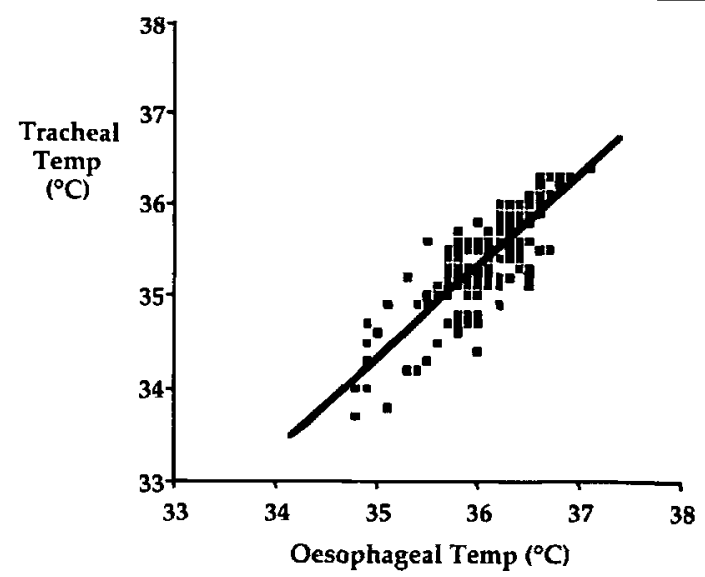

FIGURE 1C 


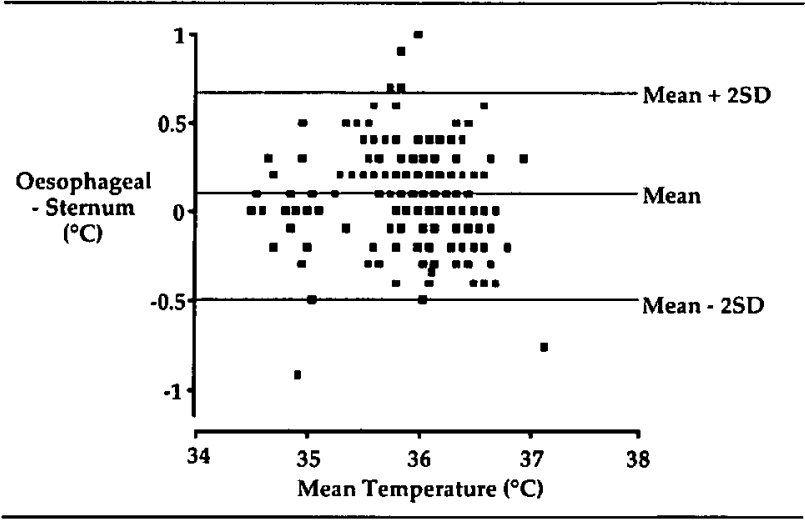

FIGURE 2 Bland and Altman comparison of distal oesophageal temperature with "deep sternal" (A), "deep forehead" (B), and tracheal (C) temperatures. The vertical axis is the difference between oesophageal and the test site. Mean temperature on the horizontal axis refers to the average between oesophageal and test temperatures at each measurement time. The mean offsets were $0.1,0.2$, and $0.7^{\circ} \mathrm{C}$, respectively. However, the standard deviations were $0.3^{\circ} \mathrm{C}$ in each case.

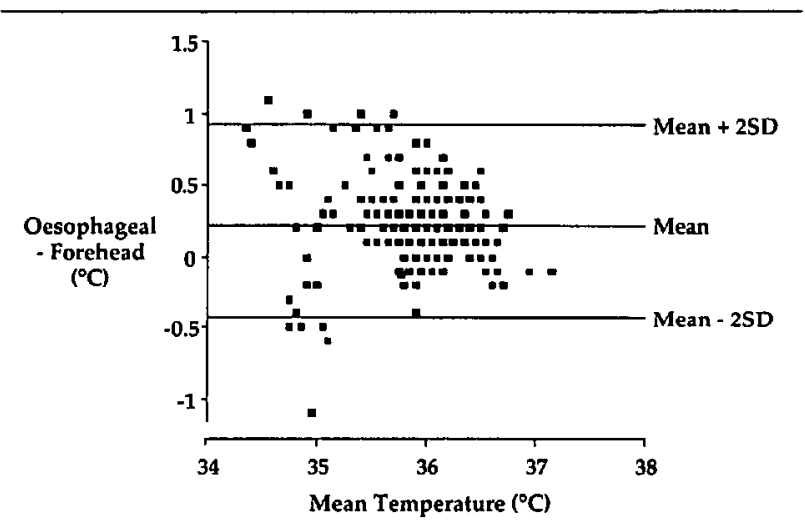

FIGURE 2B

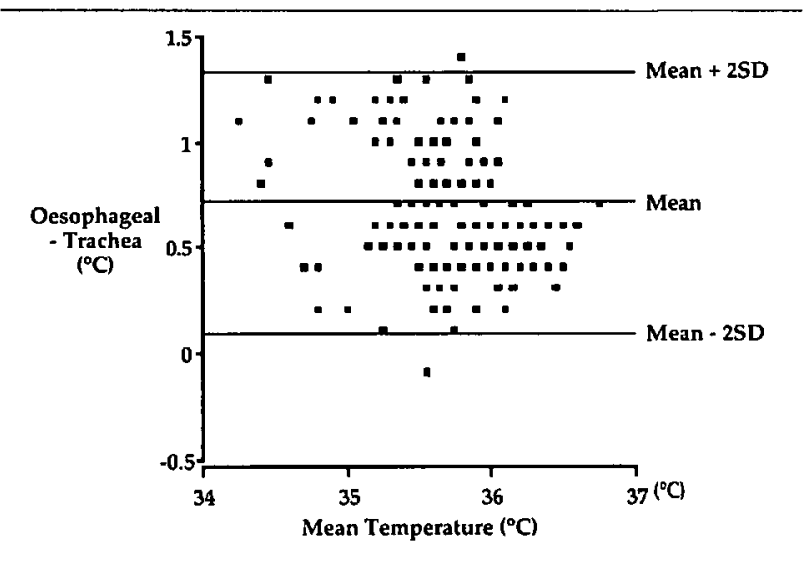

FIGURE 2C $\left(0.7^{\circ} \mathrm{C}\right)$ than for the other sites $\left(0.2^{\circ} \mathrm{C}\right)$. Therefore, we are able to rely on and we foresee the trend of core temperature monitoring with "deep" sternal, and forehead temperatures. However, because of the larger positive offset for tracheal temperature, hyperthermia, an important symptom of malignant hyperthermia, could be underestimated.

The oesophagus remains among the most common core-temperature monitoring sites during general anaesthesia. However, oesophageal temperature probes are difficult to position in patients receiving lung ventilation via laryngeal mask airways. Furthermore, oesophageal stethoscopes - once routine - have been partially supplanted by end-tidal $\mathrm{PCO}_{2}$ monitoring. Finally, the extent of hypothermia during regional anaesthesia has received increasing recognition. Patients undergoing regional anaesthesia are presumably also susceptible to most hypothermia-induced complications. These factors have prompted a search for alternative core-temperature monitoring methods.

The first alternative temperature monitoring method we considered was the trachea. Alveolar gas is at core temperature but the potential difficulty with tracheal temperature monitoring is that the temperature sensor may be sufficiently proximal to be cooled considerably respiratory gases. The critical innovation in tracheal temperature monitoring was to position the temperature sensor on the tracheal cuff periphery, thus keeping it in continuous contact with tracheal tissue while simultaneously shielding it from the cooling effects of tracheal gases. ${ }^{21}$

In the absence of respiratory gas heating and humidification, and at the $6 \mathrm{~L} \cdot \mathrm{min}^{-1}$ fresh gas flow rate used in our analysis, the accuracy of tracheal temperature was relatively poor whereas precision was adequate. Our data suggest that tracheal temperatures may not be an adequate substitute for conventional core-temperature monitoring sites. This conclusion differs from a previous report, ${ }^{21}$ possibly because regression analysis was used in that study without a corresponding Bland and Altman analysis over a range of core temperatures from 28 to $37^{\circ} \mathrm{C}$. This difference emphasizes how regression analysis alone (especially over a wide range of values) often fails to provide all the information required to evaluate new technology. One other study evaluated the ability of tracheal temperature to substitute for core temperature during cardiopulmonary bypass. ${ }^{20} \mathrm{~A}$ fresh gas flow of $4 \mathrm{~L} \cdot \mathrm{min}^{-1}$ was used in that study, but the abstract does not specify if airway heating and humidification were used. The authors found that the offset was relatively low $\left(0.26^{\circ} \mathrm{C}\right)$, but that the standard deviation of the difference was an unacceptable $0.94^{\circ} \mathrm{C}$. 
The second monitoring method we evaluated was deep tissue temperature. In the absence of blood-borne convection of heat, all tissues under the centre of an infinitely large sensor disk would also equal core temperature. Convection within tissues disturbs the theoretical equi-temperature column below the sensor disk. Our data nonetheless indicate that both the accuracy and precision of deep-tissue temperature monitoring at the sternum and forehead is sufficient for clinical use. Clinicians can thus use whichever site is more convenient, depending upon the position of the patient and the site of surgery. This finding confirms previous work. $25,26,28$

The core temperature range evaluated in this study spanned only $2^{\circ} \mathrm{C}$. However, most surgical patients are maintained within this range to prevent hypothermia-induced complications. A potential difficulty with deep tissue temperature monitoring is that producing an equilibrium between the disk surfaces and tissue layers generally requires $15 \mathrm{~min}$, depending on the site measured, ambient temperature, and initial tissue temperature. We consequently recorded our first measurements $15 \mathrm{~min}$ after the sensor was positioned. We made no effort to establish the time course of this equilibration, as it is already known to be exponential.

Intraoperative core temperature monitoring became routine in the $19 \%$ s, following recognition that malignant hyperthermia was a major cause of preventable anaesthetic mortality. ${ }^{12}$ Temperature monitoring continues to facilitate diagnosis of the syndrome, although end-tidal $\mathrm{PCO}_{2}$ monitoring - now required by the American Society of Anesthesiologists to document adequate ventilation - is more sensitive. ${ }^{29}$ Inadvertent hypothermia, however, is far more common than malignant hyperthermia. Even mild hypothermia adversely may influences patient outcome. ${ }^{8-10}$ In addition, hyperthermia is not the first sign of malignant hyperthermia. However, increased core temperature indisputably facilitates interpretation of other nonspecific signs of the syndrome, such as tachycardia and hypercarbia. Other causes of intraoperative hyperthermia also need to be detected and appropriately treated.

In summary, we compared distal oesophageal temperature with "dieep-sternal," "deep-forehead," and tracheal temperatures in 20 patients undergoing general anaesthesia for gynaecological surgery. The accuracy of tracheal temperature was relatively poor under the conditions of our study, whereas precision was adequate. Our data suggest that tracheal temperatures are not an adequate substitute for conventional coretemperature monitoring sites. In contrast, the accuracy and precision of deep-tissue temperature monitoring at the sternum and forehead was sufficient for clinical use.

\section{References}

1 Vaughan MS, Vaughan RW, Cork RC. Postoperative hypothermia in adults: relationship of age, anesthesia, and shivering to rewarming. Anesth Analg 1981; 60: 746-51.

2 Leslie K, Sessler DI, Bjorksten AR, Moayeri A. Mild hypothermia alters propofol pharmacokinetics and increases the duration of action of atracurium. Anesth Analg 1995; 80: 1007-14.

3 Heier T, Caldwell JE, Sharma ML, Gruenke LD, Miller $R D$. Mild intraoperative hypothermia does not change the pharmacodynamics (concentration-effect relationship) of vecuronium in humans. Anesth Analg 1994; 78: 973-7.

4 Weeks $D B$. A laboratory evaluation of recently available heat-and-moisture exchangers. Anesthesiology Review 1986; 13: 33-6.

5 Valeri $C R$, Khabbaz K, Khuri SF, et al. Effect of skin temperature on platelet function in patients undergoing extracorporeal bypass. J Thorac Cardiovasc Surg 1992; 104: 108-16.

6 Staab DB, Sorensen VJ, Fath J, Raman SBK, Horst $H M$, Obeid $F N$. Coagulation defects resulting from ambient temperature-induced hypothermia. J Trauma 1994; 36: 634-8.

7 Sessler DI, Ponte J. Shivering during epidural anesthesia. Anesthesiology 1990; 72: 816-21.

8 Lenhardt R, Kurz A, Sessler DI, Marker E, Narzt E, Lackner $F$. Intraoperative hypothermia prolongs duration of postoperative recovery. Anesthesiology 1995; 83: Al114.

9 Schmied H, Kurz A, Sessler DI, Kozek S, Reiter A. Mild hypothermia increases blood loss and transfusion requirements during total hip arthroplasty. Lancet 1996; 347: 289-92.

10 Frank SM, Beattie C, Christopherson R, et al. Unintentional hypothermia is associated with postoperative myocardial ischemia. Anesthesiology 1993; 78: 468-76.

11 Kurz A, Sessler DI, Lenbardt RA. Perioperative normothermia to reduce the incidence of surgical-wound infection and shorten hospitalization. $\mathrm{N}$ Engl J Med 1996; 334: 1209-15.

12 Sessler DI. Malignant hyperthermia. J Pediatr 1986; 109: 9-14.

13 Frank SM, Beattie C, Christopherson $R$, et al. Epidural versus general anesthesia, ambient operating room temperature, and patient age as predictors of inadvertent hypothermia. Anesthesiology 1992; 77: 252-7.

14 Cork RC, Vaughan RW, Humphrey LS. Precision and accuracy of intraoperative temperature monitoring. Anesth Analg 1983; 62: 211-4. 
15 Webb GE. Comparison of esophageal and tympanic temperature monitoring during cardiopulmonary bypass. Anesth Analg 1973; 52: 729-33.

16 Tandberg D, Sklar D. Effect of tachypnea on the estimation of body temperature by an oral thermometer. N Engl J Med 1983; 308: 945-6.

17 Ogren JM. The inaccuracy of axillary temperatures measured with an electronic thermometer. American Journal of Disease of Children 1990; 144: 109-11.

18 Ash CJ, Cook JR, McMurry TA, Auner CR. The use of rectal temperature to monitor heat stroke. Missouri Medicine 1992; 89: 283-8.

19 Hayes JK, Collette DJ, Smith KW, Peters JL. Monitoring body-core temperature from the trachea. Anesthesiology 1995; 83: A402.

20 Kawano $Y$, Imai $M$, Komura $\Upsilon$, Kikuchi N, Kemmotsu $O$. Tracheal cuff as a new core temperature site. Anesthesiology 1992; 77: A563.

21 Yamakage $M$, Kawana $S$, Watanabe $H$. The utility of tracheal temperature monitoring. Anesth Analg 1993; 76: 795-9.

22 Fox RH, Solman AJ, Isaacs R, Fry AJ, MacDonald IC. A new method for monitoring deep body temperature from the skin surface. Clin Sci 1973; 44: 81-6.

23 Kobayashi $T$, Nemoto $T$, Kamiya A, Togawa $T$. Improvement of deep body thermometer for man. Ann Biomed Eng 1975; 3: 181-8.

24 Fox $R H$, Solman $A J$. A new technique for monitoring the deep body temperature in man from the intact skin surface. J Physiol (Lond) 1970; 212: 8-10.

25 Togawa T, Nemoto T, Yamazaki T, Kobayasbi T. A modified internal temperature measurement device. Medical \& Biological Engineering 1976; 14: 361-4.

26 Tsuji $T$. Patient monitoring during and after open heart surgery by an improved deep body thermometer. Medical Progress through Technology 1987; 12: 25-38.

27 Bland JM, Altman DG. Statistical methods for assessing agreement between two methods of clinical measurement. Lancet 1986; 1: 307-10.

28 Murapchick S. Deep body thermometry during general anesthesia. Anesthesiology 1983; 58: 271-5.

29 Baudendistel L, Goudsouzian N, Coté C, Strafford $M$. End-tidal $\mathrm{CO}_{2}$ monitoring. Its use in the diagnosis and management of malignant hyperthermia. Anaesthesia 1984; 39: 1000-3. 